Bài báo khoa học

\title{
Đánh giá quy trình quản lý rủi ro thiên tai tại huyện Mỹ Xuyên, tỉnh Sóc Trăng
}

\author{
Võ Thị Phương Linh ${ }^{1}$, Nguyễn Hiếu Trung ${ }^{2}$, Võ Quốc Thành ${ }^{1 *}$ \\ ${ }^{1}$ Khoa Môi trường và TNTN, Trường Đại học Cần Thơ; vtplinh@ctu.edu.vn; \\ quocthanh@ctu.edu.vn \\ ${ }^{2}$ Viện Nghiên cứu Biến đổi Khí hậu, Trường Đại học Cần Thơ; nhtrung@ctu.edu.vn \\ *Tác giả liên hệ: quocthanh@ctu.edu.vn; Tel.: +84-945152202
}

Ban Biên tập nhận bài: 05/9/2021; Ngày phản biện xong: 01/11/2021; Ngày đăng bài: $25 / 1 / 2022$

Tóm tắt: Nghiên cứu dựa trên cách tiếp cận ở mức độ phân tích toàn diện các giai đoạn cũng như các bên liên quan tham gia trong quy trình quản lý rủi ro thiên tai. Số liệu về các loại thiên tai và thiệt hại do thiên tai giai đoạn 2014 đến 2019 được thu thập từ các cơ quan địa phương kết hợp phỏng vấn nông hộ và cán bộ về quá trình chuẩn bị, ứng phó và phục hồi sau thiên tai. Phương pháp kiểm định phi tham số được sử dụng để so sánh mức độ thiệt hại do thiên tai giữa các mô hình canh tác. Kết quả xác định ba loại thiên tai thường xuyên xuất hiện gồm: (1) xâm nhập mặn, (2) giông lốc, (3) bão và áp thấp nhiệt đới. Quy trình quản lý rủi ro thiên tai có sự tham gia của các bên liên quan như: Ban Chỉ huy Phòng chống Thiên tai và Tìm kiếm Cứu nạn, các Phòng Ban chức năng và Ủy ban Nhân dân Xã. Các biện pháp đã và đang được áp dụng như: thay đổi lịch thời vụ, vận hành hệ thống công trình thủy lợi để ứng phó và hỗ trợ thiệt hại cho người dân. Quá trình được tổ chức chặt chẽ nhưng có thể bị động trong việc huy động nhân lực, trang thiết bị và nguồn kinh phí hỗ trợ người dân phục hồi sau thiên tai còn hạn chế.

Từ khóa: Mỹ Xuyên; Phục hồi; Sóc Trăng; Thiên tai; Ứng phó.

\section{Mở đầu}

Theo Tổ chức Lương thực và Nông nghiệp của Liên hợp quốc $(F A O)$ [1], từ năm 2005 đến 2015 , thiên tai đã gây thiệt hại cho nông nghiệp của các nền kinh tế đang phát triển với tổng thiệt hại khoảng 96 tỉ đô la, bao gồm hư hại và mất trắng về cây trồng và vật nuôi. Trong đó, hạn hán là một trong những nguyên nhân gây khó khăn cho sản xuất nông nghiệp trên toàn thế giới. Ngoài ra, các yếu tố khác như bão, lũ lụt, xâm nhập mặn cũng gây hậu quả nghiêm trọng cho sản xuất nông nghiệp, an ninh lượng thực và sinh kế của người dân. Do đó, nghiên cứu đánh giá rủi ro thiên tai đã được chú trọng trong những năm gần đây với nhiều cách tiếp cận khác nhau.

Một số nghiên cứu đã được thực hiện như đánh giá rủi ro thiên tai do lũ và ngập lụt cho Greater Manchester (Anh Quốc) [2], đánh giá rủi ro ngập lụt có thể xảy ra trong tương lai dưới tác động của nước biển dâng cho bờ biển $\mathrm{Ba}$ Lan [3], đánh giá các phương án thích ứng với mực nước biển dâng và lợi ích đối với nông nghiệp tại đồng bằng sông Ebro [4]. Tại Việt Nam, một số nghiên cứu về rủi ro thiên tai cũng đã được thực hiện như đánh giá rủi ro thiên tai do lũ lụt khu vực Trung Trung bộ [5], đánh giá rủi ro thiên tai liên quan đến biến đổi khí hậu dựa vào cộng đồng cho các xã ven biển tỉnh Quảng Bình [6], đánh giá ảnh hưởng của sử dụng đất đến kết quả tính toán chỉ số dễ bị tổn thương do lũ cho huyện Điện Bàn, tỉnh Quảng 
Nam thuộc hạ du lưu vực sông Thu Bồn [7]; đánh giá rủi ro thiên tai do lũ lụt sông Dinh [8]. Tại đồng bằng sông Cửu Long (ĐBSCL) cũng đã có một số nghiên cứu về rủi ro thiên tai như nghiên cứu đánh giá mức độ rủi ro lũ lụt tỉnh An Giang trong trường hợp lũ cao và đề xuất các biện pháp quản lý [9], ứng dụng phân tích đa tiêu chí trong đánh giá ảnh hưởng của biến đổi khí hậu đối với sản xuất nông nghiệp ở các tỉnh ven biển ĐBSCL [10], xây dựng bản đồ hạn hán đồng bằng sông Cửu Long trong bối cảnh biến đổi khí hậu [11]. Nhìn chung, các nghiên cứu này tập trung vào việc (1) đánh giá rủi ro trước thiên tai nhằm dự báo, xác định rủi ro trước khi thiên tai xảy ra và (2) đánh giá rủi ro sau thiên tai nhằm xác định những thiệt hại do thiên tai gây ra trong quá khứ từ đó cảnh báo về thiệt hại có thể xảy ra trong tương lai.

Trong khi đó, Luật phòng, chống thiên tai của Việt Nam [12] nhấn mạnh nguyên tắc cơ bản trong phòng chống thiên tai là phòng ngừa chủ động, ứng phó kịp thời, khắc phục khẩn trương và hiệu quả. Do vậy, bên cạnh việc đánh giá rủi ro trước và sau thiên tai thì việc quản lý để chủ động ứng phó, phục hồi sau thiên tai là cần thiết nhằm giảm nhẹ, hạn chế tác động của thiên tai. Theo đó, một số nghiên cứu tiếp cận theo hướng này cũng đã được thực hiện. Tuy nhiên, đa phần các nghiên cứu chủ yếu đánh giá trên một nhóm đối tượng riêng lẻ, chẳng hạn như đánh giá vai trò của ngành công an trong công tác ứng phó với biến đổi khí hậu, phòng chống thiên tai và tìm kiếm cứu nạn [13]; hay nhận diện niềm tin tại cộng đồng dân cư ven biển trong ứng phó với thiên tai [14]. Một số nghiên cứu khác thực hiện đánh giá trong quá trình ứng phó [15] hoặc trong quá trình phục hồi [16]. Trong khi đó, theo [17] quy trình quản lý thiên tai khép kín (Disaster management cycle) được mô tả bao gồm ba giai đoạn: (1) quá trình chuẩn bị (trước khi thiên tai xảy ra), quá trình ứng phó (khi thiên tai xảy ra) và (3) quá trình phục hồi (sau khi thiên tai xảy ra). Hiện nay, nghiên cứu đánh giá toàn diện về sự phối hợp, vai trò của tất cả các bên liên quan cũng như trong tất cả các giai đoạn của quy trình quản lý rủi ro thiên tai khép kín vẫn còn hạn chế. Do đó, nghiên cứu được thực hiện dựa trên cách tiếp cận ở mức độ phân tích toàn diện các giai đoạn cũng như các bên liên quan tham gia trong quy trình quản lý rủi ro thiên tai, các mục tiêu cụ thể như sau: (1) Xác định các loại thiên tai thường xuyên xảy ra tại vùng nghiên cứu, (2) Đánh giá tác động của thiên tai đối với vùng nghiên cứu, (3) Xác định các bên liên quan và vai trò của từng bên trong công tác ứng phó và phục hồi sau thiên tai, và (4) Đánh giá chung về việc thực hiện quản lý rủi ro thiên tai của vùng nghiên cứu. Nghiên cứu dựa trên việc thu thập các số liệu diễn biến thiên tai, thiệt hại do thiên tai, các văn bản pháp luật, khung pháp lí hiện hành kết hợp với các báo cáo về kế hoạch, hành động của các cấp chính quyền địa phương trong việc ứng phó, phục hồi sau thiên tai. Sau đó, sử dụng các phương pháp thống kê cơ bản như thống kê mô tả, kiểm định phi tham số để phân tích và xử lý số liệu.

\section{Phương pháp nghiên cứu}

\subsection{Khu vưc nghiên cúu}

Việt Nam là một trong năm nước chịu ảnh hưởng nặng nề nhất của thiên tai và biến đổi khí hậu $(\mathrm{BĐKH})$, đặc biệt là khu vực đồng bằng sông Cửu Long [18-19]. Sóc Trăng là một tỉnh ven biển đồng bằng sông Cửu Long, nằm ở cuối nguồn sông Mekong (Hình 1 ) với đường bờ biển dài $72 \mathrm{~km}$, có địa hình thấp và bằng phẳng, độ cao trung bình vùng nội đồng từ $0,5-$ $1,0 \mathrm{~m}$ so với mực nước biển [20]. Do vậy, theo kịch bản biến đổi khí hậu và nước biển dâng, Sóc Trăng là một trong 10 tỉnh chịu ảnh hưởng nặng nề nhất, nếu mực nước biển dâng cao 1 $\mathrm{m}$ vào năm 2100 , Sóc Trăng sẽ bị ngập $45 \%$ diện tích tự nhiên khi triều thấp và ngập trên $72 \%$ diện tích tự nhiên khi triều cao. Nông nghiệp và thủy sản là hai thế mạnh của tỉnh sẽ bị ảnh hưởng trước tiên, đe dọa và ảnh hưởng đến cuộc sống người dân và là thách thức đối với tỉnh trong thời gian tới. Theo đó, Mỹ Xuyên là một huyện nằm ở phía Nam của tỉnh Sóc Trăng chuyên về sản xuất nông nghiệp và nuôi trồng thủy sản (Hình 1). Với vị trí tiếp giáp giữa vùng ven biển và nội đồng nên huyện Mỹ Xuyên có 3 vùng sinh thái chính bao gồm 
vùng nước ngọt, nước lợ và nước mặn [21], trong từng vùng sinh thái có nhiều loại hình sản xuất khác nhau tạo nên sự đa dạng về sản xuất nông nghiệp. Tuy nhiên, sự đa dạng đó dẫn đến tính dễ nhạy cảm với những thay đổi bất thường của tự nhiên gây nhiều khó khăn cho sản xuất nông nghiệp trong hiện tại và tương lai. Theo [22], tỉnh Sóc Trăng nói chung thường bị ảnh hưởng bởi các loại hình thiên tai như bão, giống lốc, sét, áp thấp nhiệt đới, hạn hán, triều cường, xâm nhập mặn; trong đó, giông lốc, bão, áp thấp nhiệt đới và xâm nhập mặn là các loại hình thiên tai thường xuyên xảy ra cũng như gây thiệt hại nhiều cho sản xuất nông nghiệp và đời sống của người dân tại huyện Mỹ Xuyên.

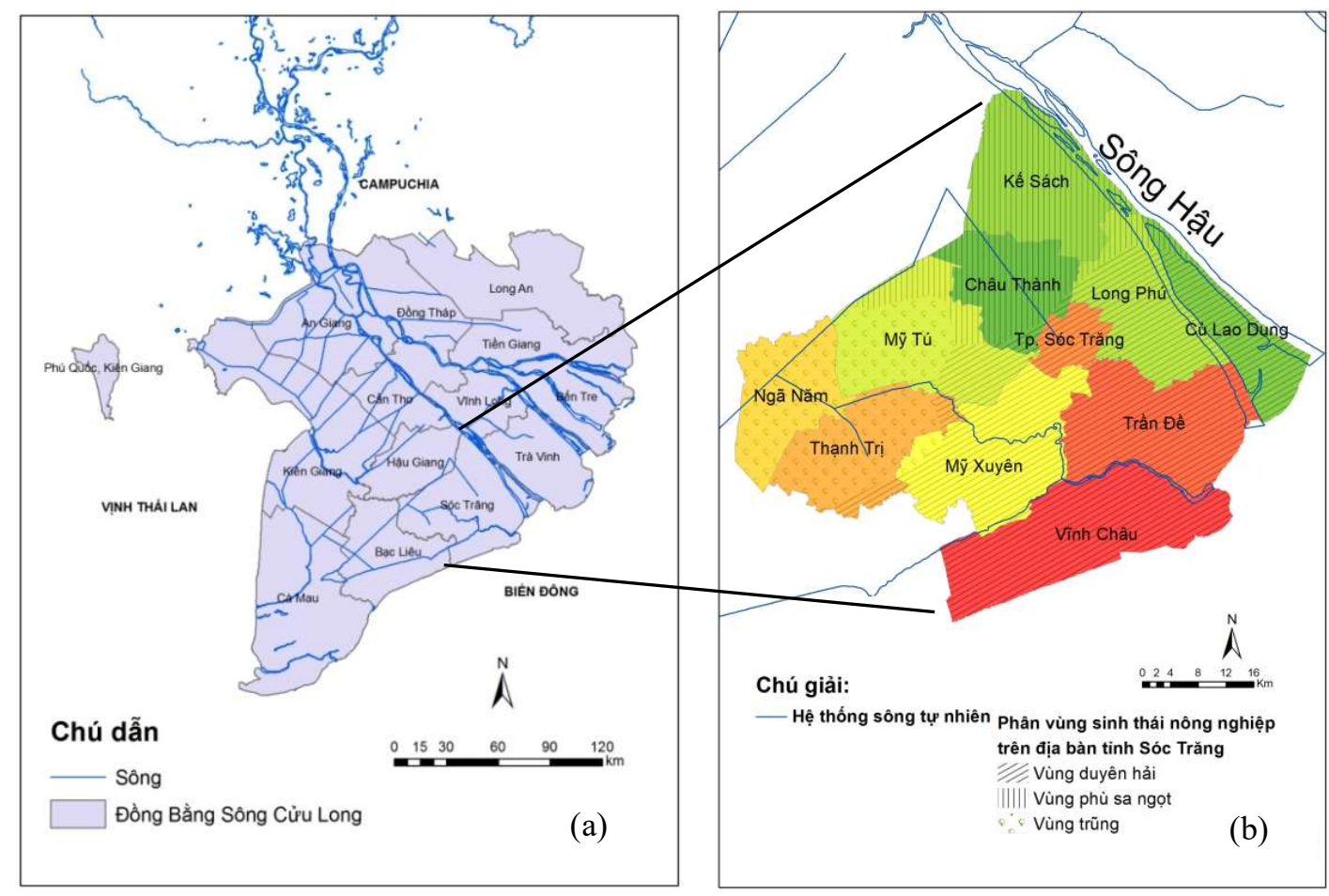

Hình 1. Đồng Bằng Sông Cửu Long (a) và Tỉnh Sóc Trăng (b).

\subsection{Thu thập số liệu nghiên cứu}

Các số liệu về chế độ thủy văn, các loại thiên tai thường xuyên xảy ra tại địa phương, thiệt hại do thiên tai gây ra và các kế hoạch ứng phó, phục hồi của địa phương trong giai đoạn 2014-2019 được thu thập từ Phòng Tài nguyên và Môi trường huyện Mỹ Xuyên và Đài Khí tượng Thủy văn tỉnh Sóc Trăng (Bảng 1).

Bảng 1. Số liệu thu thập.

\begin{tabular}{|c|c|c|}
\hline STT & Số liệu thu thập & Nguồn cung cấp số liệu \\
\hline 1 & $\begin{array}{l}\text { Số cơn bão, áp thấp nhiệt đới, giông, độ mặn, nhiệt } \\
\text { độ, lượng mưa }\end{array}$ & Đài Khí tượng Thủy văn Tỉnh Sóc Trăng \\
\hline 2 & Số liệu về thiệt hại do thiên tai gây ra cho địa phương & Phòng Nông nghiệp và PTNT \\
\hline 3 & $\begin{array}{l}\text { Các kế hoạch ứng phó và phục hồi thiên tai tại địa } \\
\text { phương }\end{array}$ & $\begin{array}{l}\text { Ban chỉ đạo phòng chống thiên tai và tìm } \\
\text { kiếm cứu nạn }\end{array}$ \\
\hline 4 & $\begin{array}{l}\text { Báo cáo tổng kết công tác phòng chống thiên tai và } \\
\text { tìm kiếm cứu nạn }\end{array}$ & Phòng Nông nghiệp và PTNT \\
\hline
\end{tabular}


Thu thập các văn bản pháp luật, khung pháp lý hiện hành nhằm xác định các bên liên quan tham gia trong công tác ứng phó và phục hồi sau thiên tai. Sau đó tiến hành phỏng vấn trực tiếp các bên liên quan nhằm xác định cụ thể vai trò, chức năng, kế hoạch, hành động và tương tác với các bên liên quan khác trong công tác chuẩn bị, ứng phó và phục hồi sau thiên tai. Bên cạnh đó, tiến hành khảo sát thực địa và phỏng vấn hộ dân phân bố đều giữa các loại hình sản xuất chính ở địa phương (chuyên lúa, lúa-tôm, chuyên tôm) tại khu vực chịu ảnh hưởng của các loại thiên tai trong giai đoạn nghiên cứu dựa trên bảng câu hỏi. Số lượng mẫu phỏng vấn 60 hộ dân về các nội dung cụ thể như sau:

- Các loại hình thiên tai thường xuyên xảy ra tại địa phương trong giai đoạn nghiên cứu, công tác chuẩn bị ứng phó đối với hộ gia đình và đánh giá của hộ gia đình về công tác hỗ trợ ứng phó của chính quyền địa phương.

- Chi phí đầu tư, lợi nhuận, mức độ thiệt, các giải pháp của gia đình và các cơ quan địa phương đã áp dụng để phục hồi sau khi thiên tai xảy ra và mức độ hài lòng của gia đình về công tác hỗ trợ khắc phục sau thiên tai của địa phương.

\subsection{Phwơng pháp xủ lý số liệu}

\subsubsection{Làm sạch dữ liệu}

Làm sạch dữ liệu bước cần thiết trong quá trình xử lý dữ liệu khảo sát để loại bỏ những lỗi trong quá trình thực hiện khảo sát trước khi dữ liệu được sử dụng để phân tích. Trong quá trình nhập và xử lý số liệu phỏng vấn, sai sót có thể xảy ra sẽ làm ảnh hưởng đến kết quả của các phân tích chuyên sâu. Do đó, các dữ liệu cần được điều chỉnh về đúng định dạng và làm dữ liệu đầu vào cho các phân tích thống kề. Do số lượng phiếu phỏng vấn không lớn nên có thể kiểm tra thủ công trong nghiên cứu này. Trong trường hợp số lượng mẫu lớn có thể kiểm tra bằng cách tính tần suất để kiểm tra những dữ liệu bất thường trong dữ liệu thu thập được.

\subsubsection{Mã hóa và kiểm tra dữ liệu}

Trong các phân tích thống kê, mã hóa dữ liệu được áp dụng phổ biến cho các là chuyển dữ liệu từ dạng này sang dạng code. Các câu trả lời từ các câu hỏi định tính sẽ được mã hóa để dễ dàng áp dụng làm đầu vào cho các phân tích sau. Ví dụ như các mô hình canh tác và các vụ sẽ được mã hóa thành các mã số riêng. Sau khi dữ liệu được mã hóa thì có thể được sử dụng để phân tích. Kiểm tra dữ liệu giúp hiểu rõ thông điệp có trong dữ liệu. Kết quả của việc kiểm tra dữ liệu đảm bảo dữ liệu đầy đủ và đáp ứng các điều kiện để phân tích thống kê.

\subsubsection{Phân tích thống kê}

\section{a. Thống kê mô tả}

Phân tích thống kê được thực hiện để phản ánh đặc tính của các loại hình thiên tai xảy ra trên địa bàn huyện Mỹ Xuyên. Phương pháp thống kê mô tả với các hàm toán học như tính giá trị trung bình (Average), tìm giá trị lớn nhất (Max), giá trị nhỏ nhất (Min) và tính các giá trị phầm trăm được sử dụng nhằm xác định diễn biến các loại hình thiên tai xảy ra.

\section{b. Kiểm định phi tham số Kruskal-Wallis}

Kiểm định phi tham số Kruskal-Wallis là phương pháp phân tích phương sai sử dụng hạng của các giá trị quan sát, dùng để so sánh trung bình của tổng thể. Đây là phương pháp được áp dụng trong những trường hợp dữ liệu không có phân phối chuẩn, đặc biệt khi mẫu nghiên cứu nhỏ, bắt buộc phải sử dụng kiểm định phi tham số. Sử dụng để kiểm định sự khác biệt về phân phối giữa ba (hoặc nhiều hơn ba) nhóm không có phương sai tương đương nhau. Trong phạm vi nghiên cứu, phương pháp kiểm định phi tham số Kruskal-Wallis được sử dụng nhằm kiểm định giả thuyết trung bình thiệt hại do thiên tai gây ra có bằng nhau giữa 
các mô hình canh tác (chuyên lúa, lúa-tôm, chuyên tôm) với mức ý nghĩa 5\%. Kết quả phân tích xác định mức độ thiệt hại do thiên tai giữa các loại hình sản xuất khác nhau. Từ đó cung cấp cơ sở cho người dân và chính quyền địa phương trong việc ứng phó và đề xuất các giải pháp (ví dụ như chuyển đổi hệ thống canh tác) để hạn chế thiệt hại do thiên tai.

\section{Kết quả và thảo luận}

\subsection{Các loại thiên tai xảy ra tại vùng nghiên cưu}

\subsubsection{Xâm nhập mặn}

Diễn biến độ mặn lớn nhất theo ngày tại trạm Thạnh Phú từ năm 2014 đến 2019 (Hình 2) cho thấy vùng nghiên cứu bị ảnh hưởng do xâm nhập mặn từ tháng 1 đến tháng 6 , trong đó, cao nhất vào giai đoạn tháng 3 đến tháng 4 . Nhìn chung, xâm nhập mặn có xu hướng tăng trong giai đoạn từ năm 2014 đến năm 2016, đặc biệt, năm 2016 là năm có độ mặn cao nhất $(13,2 \mathrm{~g} / 1)$ và thời gian xâm nhập mặn liên tục kéo dài (thời gian xâm nhập mặn với độ mặn $\geq$ $2 \mathrm{~g} / \mathrm{L}$ kéo dài liên tục từ tháng 1 đến tháng 5 ). Giai đoạn từ năm 2016 đến năm 2019, xâm nhập mặn có xu hướng giảm và thời gian xâm nhập mặn liên tục (với độ mặn $\geq 2 \mathrm{~g} / \mathrm{L}$ ) cũng ngắn hơn so với giai đoạn trước. Kết quả này phù hợp với diễn biến năng suất lúa trung bình qua các năm tại vùng nghiên cứu (Hình 3). Cụ thể, mặc dù năm 2016 có tổng diện tích lúa gieo trồng cao nhất nhưng lại có năng suất thấp nhất trong giai đoạn 2014-2019 và từ năm 2017-2019, năng suất lúa có cải thiện hơn so với năm 2016. Theo [23] tùy từng giống lúa và giai đoạn phát triển mà có ngưỡng độ mặn ảnh hưởng khác nhau, nhưng nhìn chung với độ mặn từ $2 \mathrm{~g} / \mathrm{L}$ đã có thể gây ảnh hưởng đến sự phát triển của cây lúa như làm giảm chiều cao cây, số chồi lúa, số hạt chắc trên bông, khối lượng hạt và nếu độ mặn vượt qua giá trị này thì năng suất lúa sẽ giảm mạnh. Mặc dù hoạt động điều tiết các công trình thủy lợi ngăn mặn của địa phương có thể tránh việc dẫn nước mặn tưới trực tiếp vào ruộng lúa; tuy nhiên, thời gian mặn kéo dài với độ mặn cao $(>2 \mathrm{~g} / \mathrm{L})$ có thể gây thiếu nước tưới. Theo [24] số lượng chồi và chiều cao cây lúa có thể bị giảm nếu thiếu nước trong quá trình sinh trưởng, đặc biệt, năng suất sẽ giảm rõ rệt nếu thiếu nước trong quá trình làm đồng - trổ bông [25]. Do đó, xâm nhập mặn được xem là loại thiên tai xảy ra thường xuyên gây ảnh hưởng đến hoạt động sản xuất và sinh hoạt của người dân tại khu vực nghiên cứu. Cụ thể, trong giai đoạn 2016-2018 đã có khoảng 2.700 ha mô hình sản xuất lúa, lúa-tôm bị ảnh hưởng do XNM. Trong đó, phần lớn bị thiệt hại ở mức độ cao (giảm năng suất hơn 70\%) (Hình 4).

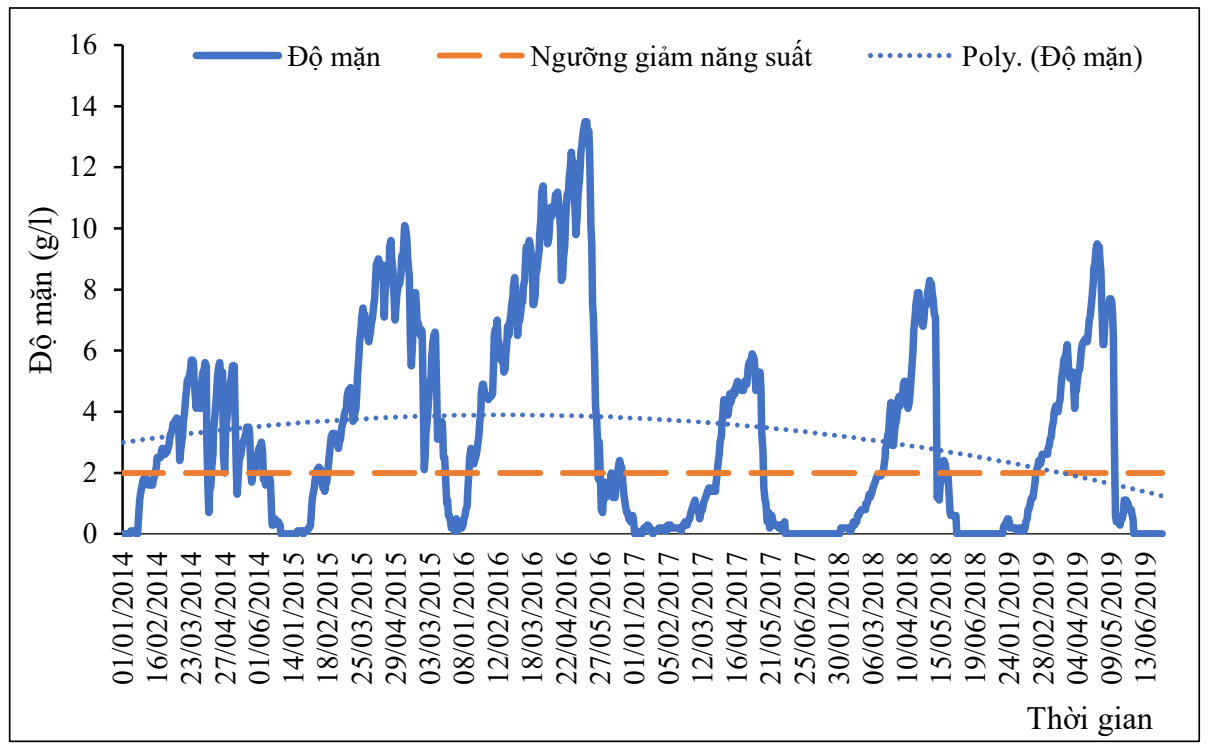

Hình 2. Độ mặn theo ngày tại trạm Thạnh Phú trong giai đoạn từ năm 2014 đến năm 2019. 


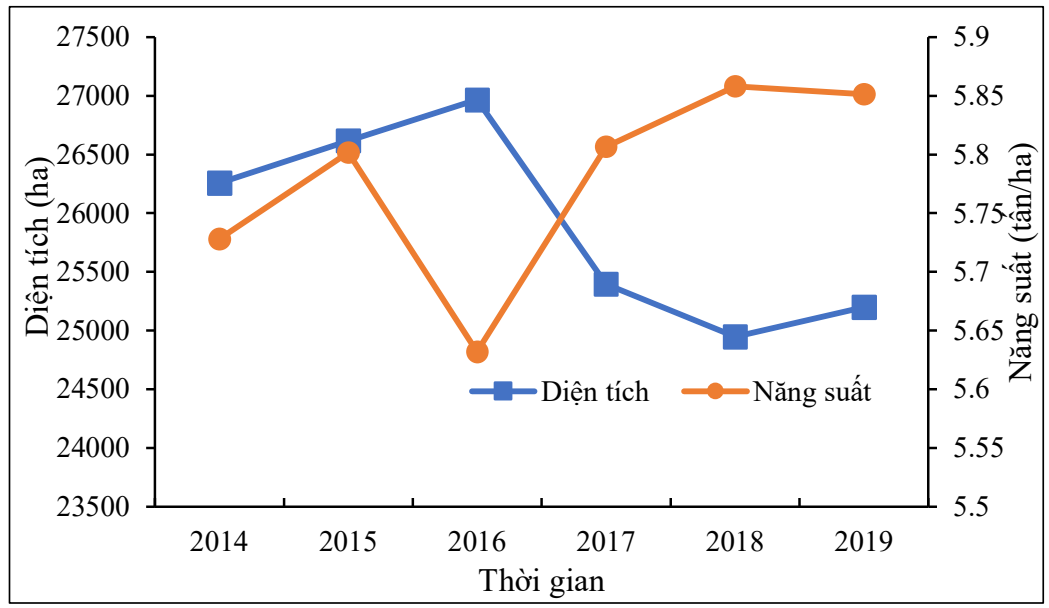

Hình 3. Năng suất và diện tích lúa tại huyện Mỹ Xuyên trong giai đoạn từ năm 2014 đến năm 2019.

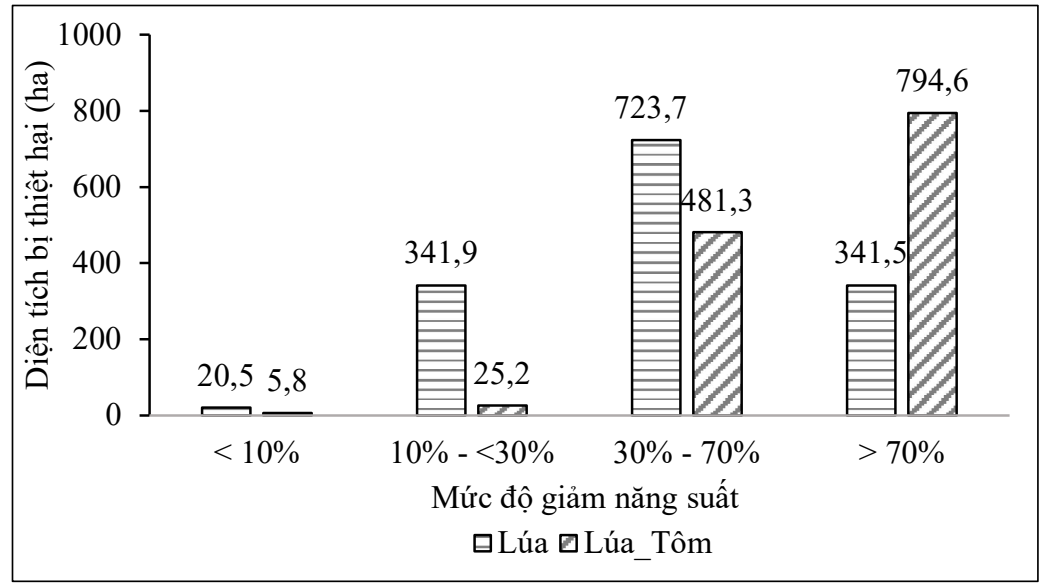

Hình 4. Diện tích lúa thiệt hại trong các hệ thống canh tác từ năm 2016-2018.

\subsubsection{Giông lốc}

Trong giai đoạn từ năm 2014 đến năm 2018 số cơn giông lốc xuất hiện trên địa bàn huyện Mỹ Xuyên dao động từ 4 đến 8 đợt/năm và nhìn chung có xu hướng ngày càng gia tăng về tần suất xuất hiện (Hình 5). Do giông lốc xảy ra khó dự báo được nên gây khó khăn cho hoạt động ứng phó và gây thiệt hại nặng nề hơn (chủ yếu về nhà cửa) cho các hộ gia đình. Cụ thể, trong giai đoạn 2014-2018, giông lốc làm hư hại nhiều căn nhà của người dân địa phương với các mức độ khác nhau; trong đó, phần lớn số căn nhà bị hư hại ở mức độ 50 $60 \%$ (593 căn, chiếm 33\%), số căn nhà bị sập hoàn toàn cũng chiếm số lượng lớn (513 căn, chiếm $28 \%$ ) (Hình 6). Phần lớn các nhà hư hại là các nhà thô sơ (không kiên cố) thuộc các các hộ nghèo hoặc cận nghèo nên khó khăn trong việc ứng phó và khắc phục.

\subsubsection{Bão và áp thấp nhiệt đới}

Theo người dân và cán bộ địa phương, bão và $\mathrm{ATNĐ} \mathrm{thường} \mathrm{xuất} \mathrm{hiện} \mathrm{nhiều} \mathrm{vào} \mathrm{mùa}$ mưa (khoảng tháng 8 đến tháng 11), với các cấp độ khác nhau sẽ gây mức thiệt hại khác nhau. Nhìn chung, số cơn bão và $\mathrm{ATNĐ} \mathrm{xuất} \mathrm{hiện} \mathrm{trên} \mathrm{biển} \mathrm{Đông} \mathrm{và} \mathrm{có} \mathrm{ảnh} \mathrm{hưởng} \mathrm{đến} \mathrm{địa}$ bàn huyện từ năm 2014-2018 có xu hướng giảm trong khi số đợt ATNĐ có xu hướng tăng (Hình 7). Tuy nhiên, số liệu ghi nhận trong giai đoạn ngắn (5 năm) nên khó phản ánh chính xác xu hướng biến động. 


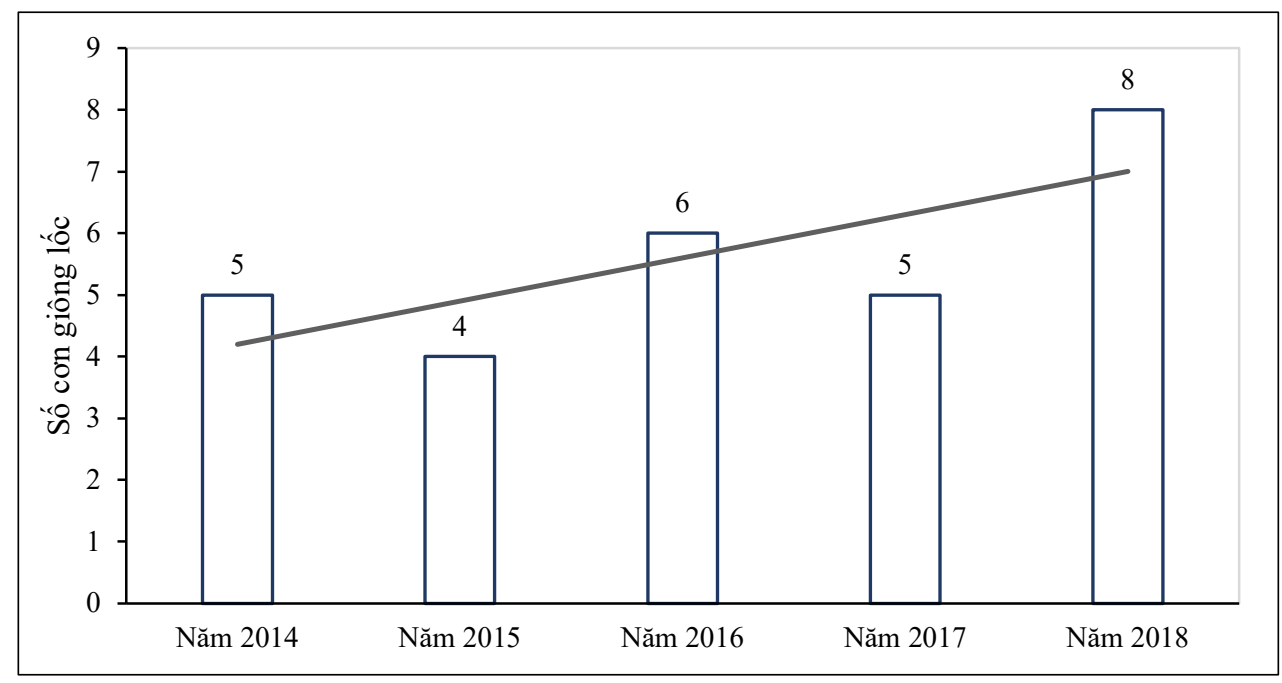

Hình 5. Số cơn giông lốc xảy ra từ năm 2014-2018.

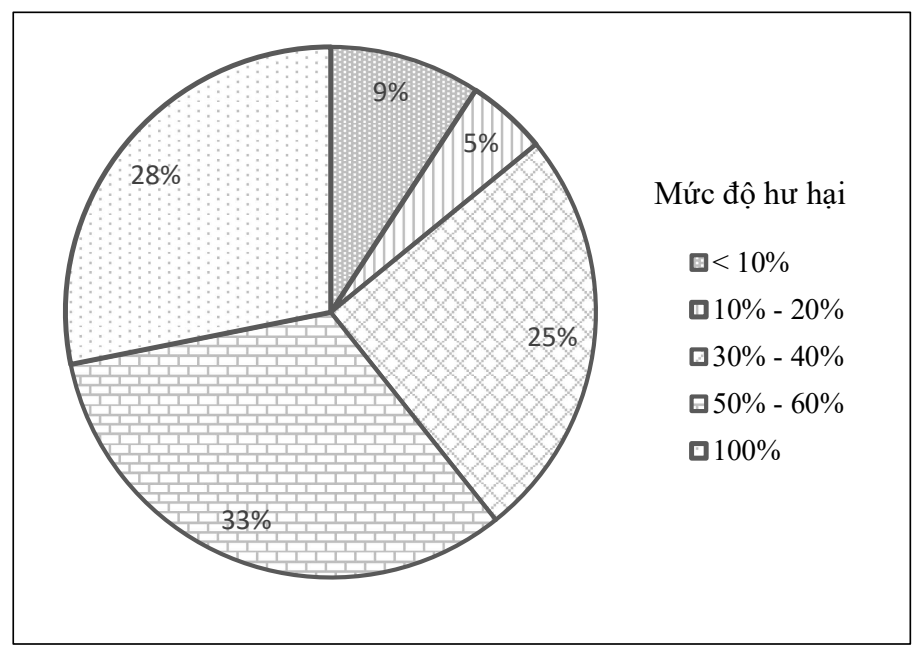

Hình 6. Số căn nhà bị thiệt hại từ năm 2014-2018.

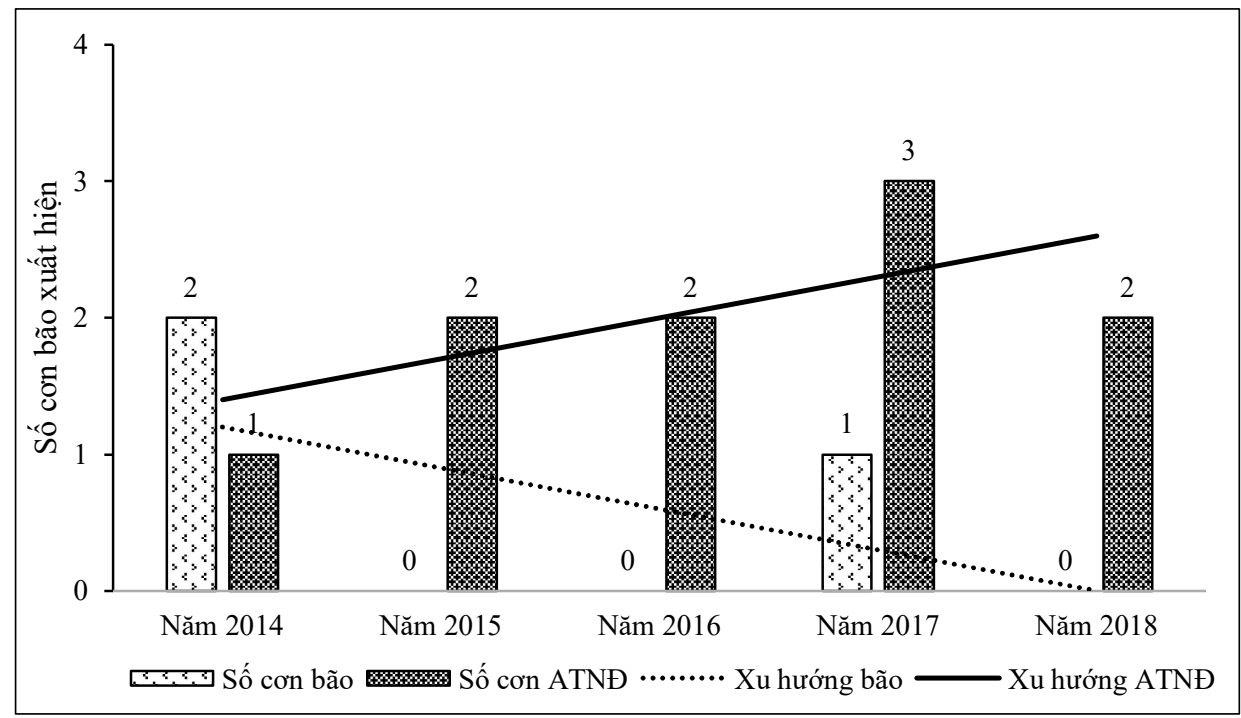

Hình 7. Số cơn bão và ATNĐ xảy ra tại huyện Mỹ Xuyên trong giai đoạn năm 2014-2018. 
Mặc dù số cơn bão và $\mathrm{ATNĐ} \mathrm{xảy} \mathrm{ra} \mathrm{tại} \mathrm{vùng} \mathrm{nghiên} \mathrm{cứu} \mathrm{không} \mathrm{nhiều} \mathrm{nhưng} \mathrm{được} \mathrm{người}$ dân và cán bộ địa phương xếp vào nhóm gây ảnh hưởng nặng nề do không xuất hiện thường xuyên theo chu kỳ mà xuất hiện bất thường, khó dự đoán. Bên cạnh đó bão, và $\mathrm{ATNĐ}$ thường kèm theo mưa lớn và gió mạnh gây ảnh hưởng nặng nề như làm giảm sản lượng nông nghiệp, hỏng các công trình thủy lợi, hư hại nhà cửa của người dân,... Trong những năm gần đây, bão và ATNĐ làm thiệt hại trên nhiều diện tích sản xuất nông nghiệp tại huyện Mỹ Xuyên (Hình 8).

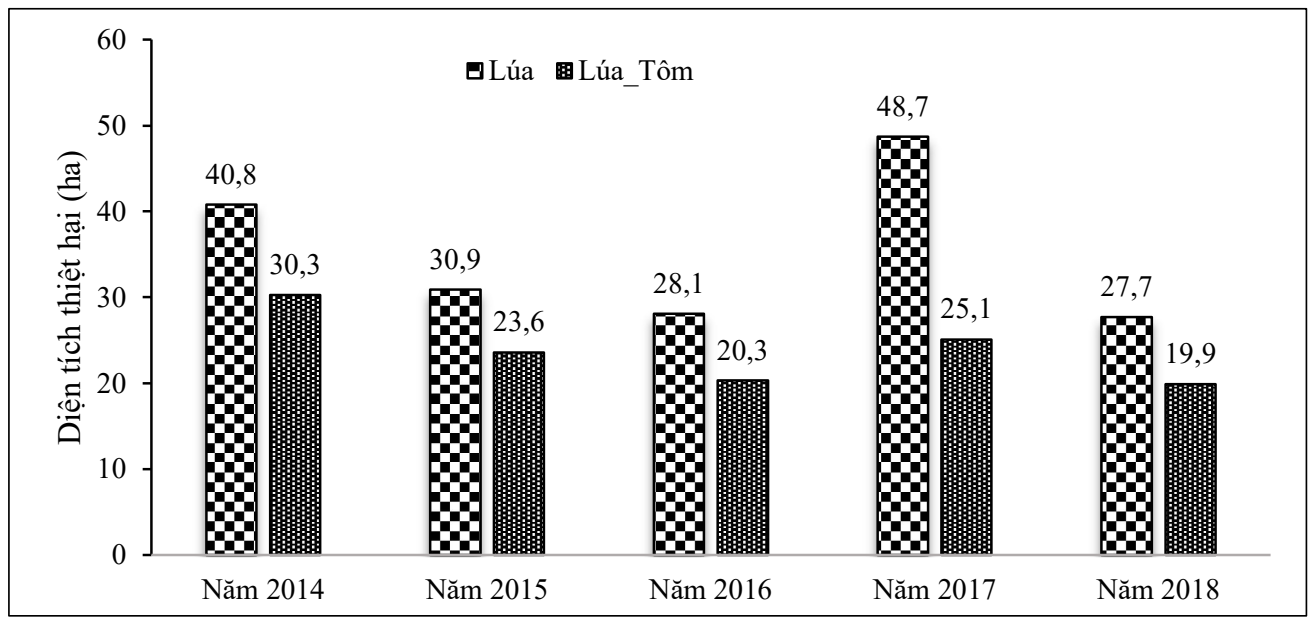

Hình 8. Thống kê thiệt hại do bão và ATNĐ từ năm 2014-2018.

\subsection{Tác động của thiên tai đối với các mô hình canh tác tại địa phương}

Huyện Mỹ Xuyên có các vùng sinh thái nước ngọt, lợ, mặn với nhiều kiểu sử dụng đất đa dạng, Trong đó, tiểu vùng nước ngọt duy trì hệ thống canh tác chuyên lúa (sản xuất lúa hai vụ/năm), tiểu vùng nước lợ duy trì hệ thống canh tác lúa trên nền tôm (sản xuất một vụ lúa, một hoặc hai vụ tôm/năm) và tiểu vùng nước mặn duy trì hệ thống canh tác chuyên tôm (sản xuất hai hoặc ba vụ tôm/năm) [9] (Hình 9).
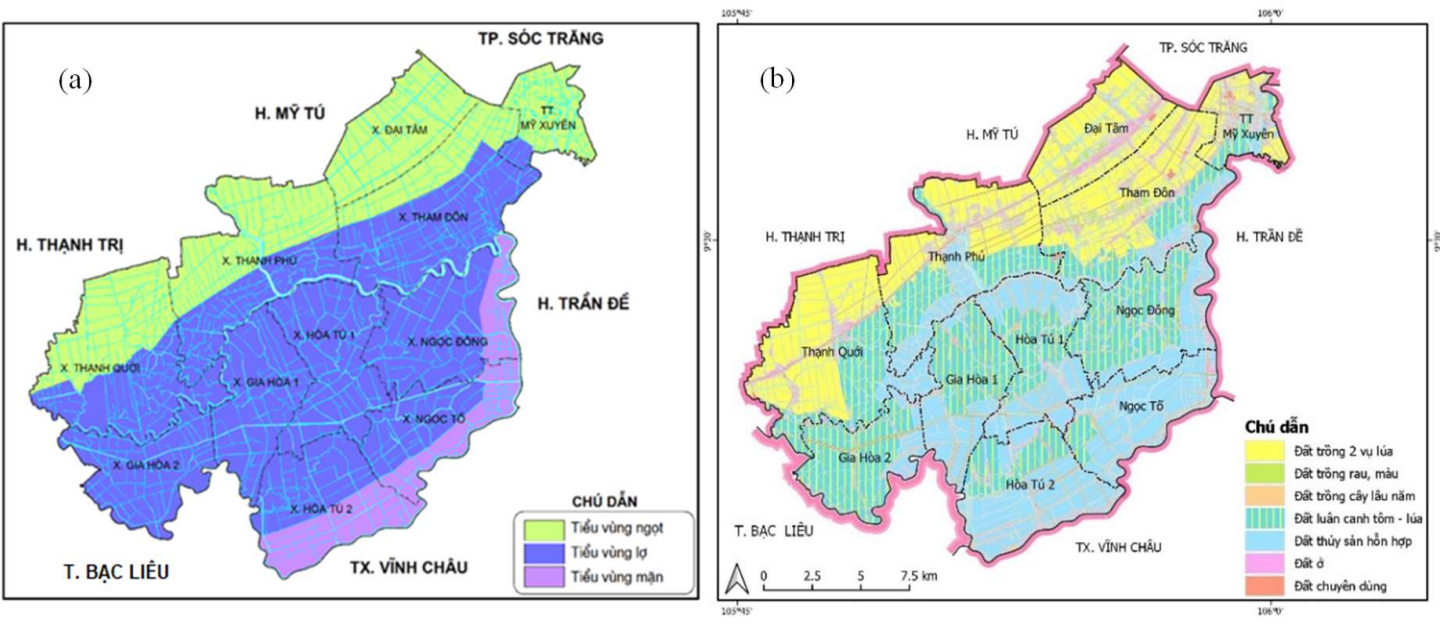

Hình 9. Bản đồ phân vùng sinh thái huyện Mỹ Xuyên (a) và Bản đồ sử dụng đất tại huyện Mỹ Xuyên cập nhật năm 2018 (b).

Kết quả khảo sát ý kiến của nông dân cho thấy do XNM xảy ra hàng năm nên được xem là yếu tố chính (chiếm $65 \%$ ) gây ảnh hưởng đến sản xuất nông nghiệp tại địa phương. Kết quả kiểm định phi tham số (Kruskal Wallis) về mức độ thiệt hại do xâm nhập mặn gây ra đối 
với ba mô hình canh tác chính (chuyên lúa, lúa-tôm, chuyên tôm) cho thấy sự có khác biệt $(\mathrm{p}<0,05)$, trong đó mô hình chuyên lúa có mức thiệt hại cao nhất, mô hình lúa-tôm xếp thứ hai và mô hình chuyên tôm ít bị thiệt hại nhất (Bảng 2), cụ thể:

Đối với mô hình chuyên lúa: Vùng nghiên cứu sản xuất hai vụ lúa/năm, bao gồm vụ đông xuân và hè thu. Trong đó, vụ đông xuân thường bắt đầu từ khoảng giữa tháng 11 kéo dài đến tháng 3 và vụ hè thu từ khoảng giữa tháng 4 và kết thúc trong tháng 8 . Do đó, về cơ bản có thể tránh được khoảng thời gian xâm nhập mặn cao nhất trong năm (tháng 3 đến tháng 4). Tuy nhiên, trong trường hợp xâm nhập mặn với độ mặn cao liên tục, kéo dài (điển hình như năm 2016) có thể tác động đến cả hai vụ lúa (cuối vụ đông xuân và đầu vụ hè thu) làm giảm năng suất từ 30-70\%, mức thiệt hại trung bình là 2,4 triệu đồng/ $1000 \mathrm{~m}^{2} /$ năm.

Đối với mô hình lúa-tôm: Xâm nhập mặn chủ yếu gây thiệt hại đến vụ lúa (vụ đông xuân kéo dài từ tháng 11 đến tháng 3) làm giảm năng suất, mức thiệt hại trung bình 1,03 triệu đồng $/ 1000 \mathrm{~m}^{2} /$ năm. Đối với vụ tôm, các vấn đề gây giảm năng suất được xác định không bao gồm xâm nhập mặn mà chủ yếu do kỹ thuật nuôi, chất lượng con giống không đảm bảo, nguồn nước ô nhiềm, nắng nóng tạo điều kiện cho mầm bệnh phát triển.

Đối với mô hình chuyên tôm: Theo kinh nghiệm sản xuất của người dân, hiện tại xâm nhập mặn chưa gây tác động trực tiếp đến việc việc nuôi tôm do độ mặn vẫn nằm trong ngưỡng phù hợp. Các vấn đề chính gây thiệt hại cho việc nuôi tôm chủ yếu do chất lượng con giống không đảm bảo, nguồn nước bi ô nhiễm, thời tiết thất thường tạo điều kiện cho mầm bệnh phát triển.

Bảng 2. Xếp hạng mức độ thiệt hại do xâm nhập mặn với các mô hình sản xuất tại huyện Mỹ Xuyên.

\begin{tabular}{ccc}
\hline Mô hình canh tác & Số mẫu & Thứ hạng \\
\hline Chuyên lúa & 21 & 48,52 \\
Lúa - tôm & 21 & 36,48 \\
Chuyên tôm & 21 & 11,00 \\
Tổng & 63 & \\
\hline
\end{tabular}

Bão, ATNĐ, giông lốc do không xuất hiện thường xuyên và chỉ xảy ra trong khoảng thời gian ngắn nên chủ yếu gây thiệt hại về nhà cửa, tài sản và con người. Đối với sản xuất nông nghiệp, bão, ATNĐ, giông lốc có thể gây ngã đổ làm giảm năng suất (đối với cây lúa), hư hại các thiết bị trong ao nuôi tôm hoặc kết hợp cùng các yếu tố khác tạo điều kiện thuận lợi cho dịch bệnh phát triển. Do tùy từng cấp độ thiên tai, diện tích bị ảnh hưởng và thời gian sinh trưởng khác nhau mà mức độ thiệt hại khác nhau nên không ước lượng được mức độ thiệt hại cụ thể đối với từng mô hình canh tác trên cùng một đơn vị diện tích. Tuy nhiên, do chi phí đầu tư cao nên các mô hình chuyên tôm, lúa-tôm có khả năng rủi ro cao hơn so với mô hình chuyên lúa (Bảng 3).

Bảng 3. Chi phí, lợi nhuận đối với các mô hình sản xuất chính tại huyện Mỹ Xuyên.

\begin{tabular}{lcccc}
\hline \multirow{2}{*}{ Mô hình canh tác } & \multicolumn{2}{c}{ Chi phí (triệu đồng) } & \multicolumn{2}{c}{ Lọi nhuận (triệu đồng) } \\
\cline { 2 - 5 } & Trung bình & stdev & Trung bình & stdev \\
\hline Chuyên lúa & 2,8 & 0,9 & 4,0 & 1,6 \\
Lúa-tôm & 10,9 & 6,0 & 35,4 & 17,0 \\
Chuyên tôm & 51,2 & 10,7 & 44,4 & 14,6 \\
\hline
\end{tabular}




\subsection{Các bên liên quan tham gia trong công tác ưng phó và phục hồi sau thiên tai}

\subsubsection{Các bên liên quan}

Công tác tổ chức thực hiện quản lý rủi ro thiên tai tại huyện Mỹ Xuyên được thể hiện như Hình 10. Theo đó, các nội dung công việc chính bao gồm: (1) Xây dựng kế hoạch ứng phó với thiên tai trên địa bàn huyện; (2) Tổ chức đào tạo, tập huấn, diễn tập ứng phó; (3) Tiếp nhận mua sắm trang thiết bị phục vụ cho việc tìm kiếm cứu nạn; và (4) Thực hiện trực và tìm kiếm cứu nạn khi thiên tai xảy ra.

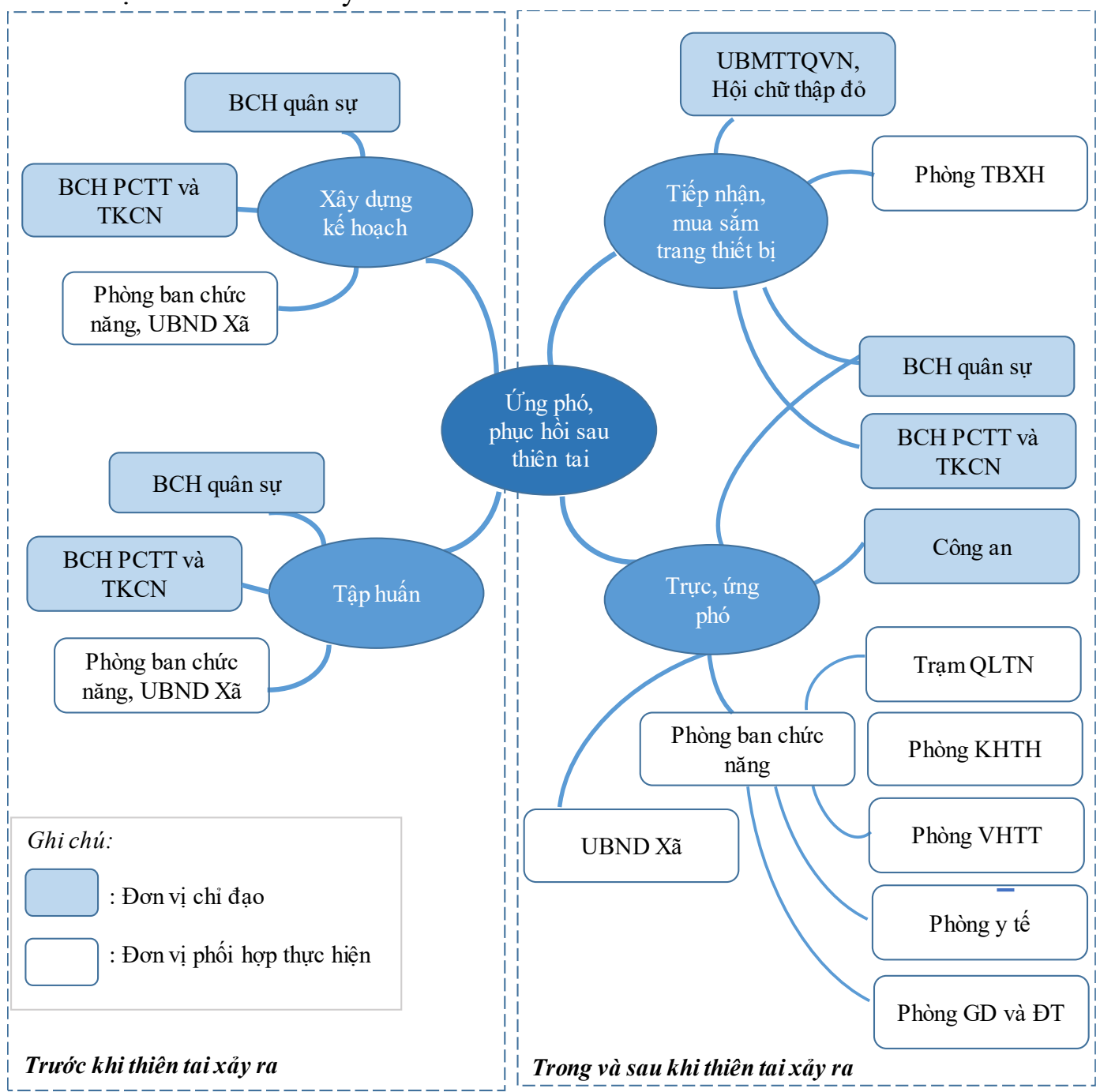

Hình 10. Tổ chức thực hiện ứng phó và phục hồi sau thiên tai.

Các nội dung công việc cụ thể như sau:

(1) Xây dựng kế hoạch ứng phó với thiên tai trên địa bàn huyện

Bao gồm xây dựng văn bản (phương án ứng phó) và xây dựng hệ thống tổ chức lực lượng tìm kiếm cứu nạn. Được thực hiện bởi các bên liên quan bao gồm: (1) Ban chỉ huy quân sự huyện (BCHQS), (2) Ban chỉ huy phòng chống thiên tai và tìm kiếm cứu nạn huyện $(\mathrm{BCH}$ PCTT và $T K C N$ ) và (3) Các phòng ban chức năng, xã, thị trấn. Trong đó $B C H Q S$ và $B C H$ PCTT và TKCN giữ vai trò chính, các phòng ban chức năng, xã, thị trấn là đơn vị phối hợp thực hiện giúp kiện toàn hệ thống tổ chức lực lượng tìm kiếm cứu nạn theo yêu cầu của $B C H Q S$ và $B C H$ PCTT và TKCN. 
(2) Tổ chức đào tạo, tập huấn, diễn tập ứng phó

$\mathrm{BCHQS}$ và $\mathrm{BCH} \mathrm{PCTT}$ và $\mathrm{TKCN}$ tiếp nhận tài liệu, giáo trình huấn luyện nghiệp vụ về ứng phó sự cố thiên tai và tìm kiếm cứu nạn từ cấp Tỉnh sau đó tổ chức tập huấn lại cho các phòng ban chức năng, xã thị trấn.

(3) Tiếp nhận mua sắm trang thiết bị phục vụ tìm kiếm cứu nạn

Được thực hiện bởi các bên liên quan bao gồm: (1) BCHQS, (2) BCH PCTT và TKCN, (3) Ủy ban mặt trận tổ quốc Việt Nam (UBMTTQVN), Hội chữ thập đỏ, và (4) Phòng thương binh xã hội (Phòng TBXH). Trong đó, $\mathrm{BCHQS}$ và $\mathrm{BCH}$ PCTT và $\mathrm{TKCN}$ chịu trách nhiệm mua sắm trang thiết bị vật tư phục vụ công tác tìm kiếm cứu nạn; UBMTTQVN, Hội chũ thập đỏ tiếp nhận các nguồn đầu tư và hỗ trợ của các tổ chức cá nhân; Phòng TBXH chịu trách nhiệm hỗ trợ trong việc vận động đóng góp các nguồn hỗ trợ công tác ứng phó và phục hồi sau thiên tai.

(4) Thực hiện trực và tìm kiếm cứu nạn trong khi thiên tai xảy ra

Được thực hiện bởi các bên liên quan gồm: (1) BCHQS, (2) BCH PCTT và TKCN và (3) Các phòng ban chức năng, xã và thị trấn. Trong đó, chịu trách nhiệm chính là $\mathrm{BCHQS}$ và $\mathrm{BCH}$ PCTT và $\mathrm{TKCN}$, các bên liên quan khác chịu trách nhiệm hỗ trợ thực hiện theo yêu cầu. Cụ thể:

Công an huyện: Đảm bảo an ninh trật tự, cứu nạn, cứu hộ, ngăn chặn và xử lý kịp thời những hiện tượng gây rối, cướp đoạt tài sản khi có thiên tai xảy ra.

Phòng kinh tế và hạ tầng huyện: Tuyên truyền và hướng dẫn người dân chằng, chống nhà cửa và cách trú ẩn an toàn tại công trình công cộng kiên cố khi có bão, giông lốc xảy ra trên địa bàn. Kiểm tra an toàn phương tiện giao thông đường thủy (đặc biệt là an toàn cho học sinh khi đi phương tiện qua sông). Đảm bảo giao thông khi thiên tai xảy ra để phục vụ công tác cứu hộ, khắc phục và huy động các phương tiện an toàn ứng cứu khi cần thiết.

Điện lực huyện: Đảm bảo nguồn điện phục vụ trong thời gian thiên tai như khắc phục sự cố điện nhằm phục hồi nguồn điện trong thời gian nhanh nhất và trang bị máy phát điện để phục vụ những nơi trọng yếu khi có thiên tai xảy ra.

Phòng văn hóa và thông tin, đài truyền thanh huyện: Phổ biến kiến thức về PCTT nhằm nâng cao nhân thức và hướng dẫn kỹ năng ứng phó các tình huống thiên tai xảy ra. Cập nhật thông tin từ Đài Khí tượng thủy văn tỉnh sau đó thông báo kịp thời, liên tục trên đài truyền thanh huyện và trạm truyền thanh xã, thị trấn để người dân chủ động phòng, tránh.

Buu điện và viễn thông huyện: Kiểm tra an toàn hệ thống thông tin liên lạc trong huyện nhằm đảm bảo thông tin xuyên suốt liên tục trong mùa mưa bão.

Phòng Giáo dục và Đào tạo huyện: Phối hợp với phòng kinh tế và hạ tầng huyện và UBND các xã, thị trấn thường xuyên kiểm tra các phương tiện tàu đò đưa rước học sinh qua sông trong, đặc biệt trong mùa mưa bão. Theo dõi diễn biến thiên tai và thông báo cho học sinh biết để có ý thức tự phòng trách

Phòng Tài chính - Kế hoạch huyện: Hướng dẫn sử dụng kinh phí đúng mục đích và cấp phát kịp thời tiền hỗ trợ khắc phục thiên tai.

Phòng y tế, bệnh viện đa khoa, trung tâm y tế dư phòng huyện: Tăng cường công tác trực ban cấp cứu, chuẩn bị đầy đủ số thuốc, chuyên môn, phương tiện và thiết bị, lương thực cứu thương kịp thời, đảm bảo công tác phòng ngừa và khắc phục hậu quả sau thiên tai.

UBND xã, thị trấn: Xây dựng và tổ chức thực hiện theo kế hoạch PCTT và TKCN với phương châm "4 tại chỗ" (chỉ huy tại chỗ, lực lượng tại chỗ, cơ sở vật chất tại chỗ, hậu cần tại chỗ). Phối hợp với các ngành, cơ quan, tổ chức di dời dân ra khỏi vùng nguy hiểm khi cần thiết. Xác định các khu vực thường xuyên bị ảnh hưởng, đối tượng, số lượng dân cần di dời. Đồng thời, chuẩn bị sẵn sàng về lực lượng, phương tiện, địa điểm sơ tán, di dời dân đến nơi an toàn.

Bên cạnh đó, đối với các loại hình thiên tai xảy ra hàng năm (điển hình như XNM) công tác ứng phó được thực hiện như: (1) Phòng NN và PTNT xây dựng kế hoạch mùa vụ hàng 
năm (dựa trên dự báo hạn mặn từ cấp Tỉnh) sau đó thông tin cho UBND Xã phổ biến đến người dân; (2) Trạm quản lý thủy nông (QLTN) đo độ mặn hàng ngày, tiến hành đóng/mở cống ngăn mặn và thông báo cho các bên liên quan khác như: Phòng $\mathrm{NN}$ và $\mathrm{PTNT}$, Đài truyền thanh để thông báo kịp thời cho người dân có kế hoạch bơm, trữ nước vào đồng ruộng.

Như vậy, nhìn chung công tác tổ chức ứng phó và phục hồi sau thiên tai tại huyện Mỹ Xuyên chặt chẽ, có sự tham gia của nhiều bên liên quan với chức năng, nhiệm vụ cụ thể có thể hỗ trợ, bổ sung cho nhau; trong đó, $\mathrm{BCH}$ PCTT và TKCN và $\mathrm{BCHQS}$ giữ vai trò chính. Tuy nhiên, vai trò của người dân (hộ gia đình) chưa được đề cao trong công tác này. Trong khi đó, người dân là người trực tiếp chịu tác động khi có thiên tai xảy ra nên bản thân họ là đối tượng cần được trang bị những kiến thức, kỹ năng và phương án ứng phó cụ thể đối với từng loại thiên tai theo các cấp độ khác nhau.

\section{4. Đánh giá công tác thực hiện quy trình quản lý rủi ro thiên tai}

Công tác chuẩn bị, ứng phó và phục hồi sau thiên tai tại địa phương được đánh giá dựa trên những nội dung trong chu trình quản lí rủi ro, thiên tai [17]. Theo đó, công tác thực hiện tại huyện Mỹ Xuyên được thể hiện như Bảng 4.

Bảng 4. Thực hiện ứng phó và phục hồi sau thiên tai tại huyện Mỹ Xuyên.

\begin{tabular}{|c|c|c|}
\hline STT & Nội dung & Thực hiện \\
\hline & Phòng ngừa & \\
\hline 1 & Căn cứ pháp lý & 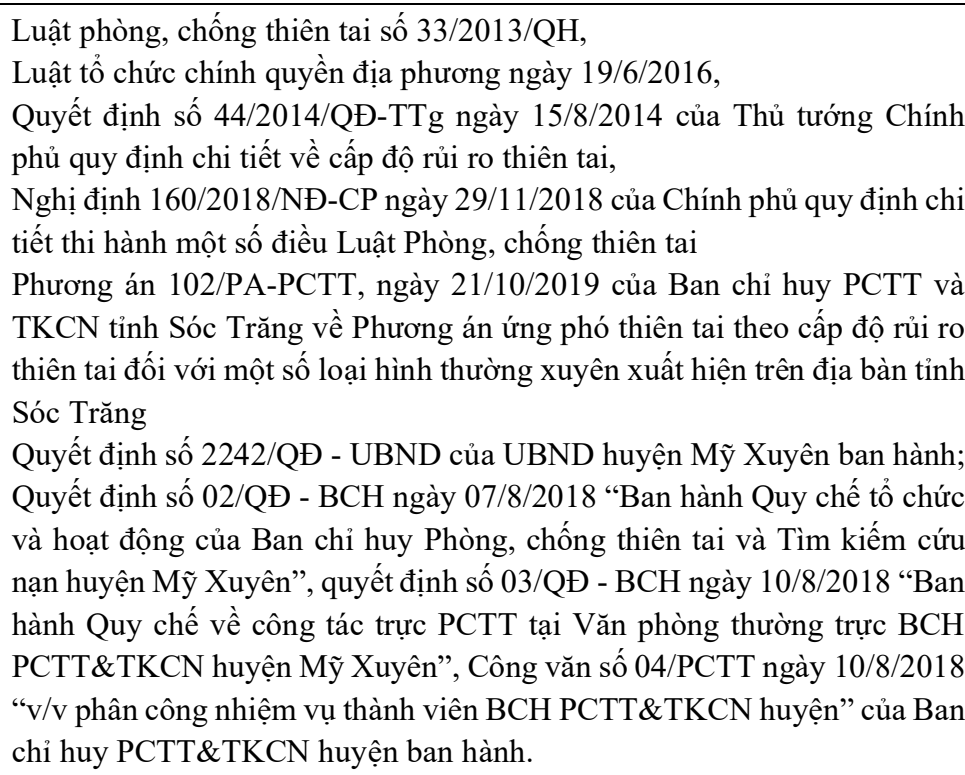 \\
\hline 2 & Quy hoạch sử dụng đất & $\begin{array}{l}\text { Có bản đồ quy hoạch sử dụng đất tại địa phương theo điều kiện riêng tại } \\
\text { từng khu vực và hàng năm có lập kế hoạch lịch thời vụ dựa trên dự báo } \\
\text { tình hình thiên tai từ cấp tỉnh }\end{array}$ \\
\hline 3 & Biện pháp kỹ thuật & $\begin{array}{l}\text { Xe cứu hộ, xe chữa cháy, tàu tìm kiếm cứu nạn, nhà bạt, phao cứu hộ, cưa } \\
\text { máy, máy phát điện và các trang thiết bị khác }\end{array}$ \\
\hline 4 & Biện pháp sinh học & $\begin{array}{l}\text { Tư vấn cho người dân các giống cây trồng, vật nuôi chống chịu với điều } \\
\text { kiện thời tiết, kháng sâu bệnh, tiêm phòng ngừa bệnh cho vật nuôi }\end{array}$ \\
\hline \multirow[t]{2}{*}{5} & Chỉ thị tổ chức & $\begin{array}{l}\text { UBND huyện chỉ đạo các Phòng ban chức năng thực hiện theo từng lĩnh } \\
\text { vực }\end{array}$ \\
\hline & Khẩn cấp & \\
\hline 1 & Quản lý & $\mathrm{BCH}$ PCTT và TKCN \\
\hline 2 & Hệ thống cảnh báo & $\begin{array}{l}\text { Đài phát thanh truyền thanh, bảng thông tin xã, ấp, loa phát thanh xã, ấp, } \\
\text { loa phát thanh lưu động, khi thiên tai có chuyến biến xấu cán bộ địa } \\
\text { phương đi đến từng hộ dân để thông báo }\end{array}$ \\
\hline
\end{tabular}




\begin{tabular}{|c|c|c|}
\hline STT & Nội dung & Thực hiện \\
\hline 3 & Các nguồn can thiệp & BCH PCTT và TKCN, BCH QS, các Phòng ban chức năng, xã thị trấn \\
\hline 4 & Kế hoạch khẩn cấp & Chủ yếu thực hiện theo phương châm "4 tại chỗ" \\
\hline 5 & Tập huấn và đào tạo & Có tổ chức tập huấn cho cán bộ các Phòng ban chức năng, xã, thị trấn \\
\hline 6 & $\begin{array}{l}\text { Chuẩn bị cho từng cá } \\
\text { nhân } \\
\text { Chuẩn bị can thiệp }\end{array}$ & Chủ yếu tuyên truyền thông qua loa, báo đài, băng rol, họp ấp... \\
\hline 1 & Cảnh báo sớm & $\begin{array}{l}\text { Xác định các loại hình thiên tai thường xuyên xảy ra trên địa bàn huyện } \\
\text { Theo dõi thông tin từ cấp Tỉnh } \\
\text { Đo độ mặn hàng ngày }\end{array}$ \\
\hline \multirow[t]{2}{*}{2} & $\begin{array}{l}\text { Chuẩn bị sẳn sàng can } \\
\text { thiệp }\end{array}$ & $\begin{array}{l}\text { BCH PCTT và TKCN huyện xây dựng kế hoạch ứng phó theo các cấp độ } \\
\text { rủi ro tại địa phương (VD: Phương án số 07/PA - BCH ngày 29/10/2018 } \\
\text { về việc ứng phó thiên tai theo cấp độ rủi ro đối với một số thiên tai ở địa } \\
\text { phương); } \\
\text { BCH QS xây dựng kế hoạch nhân sự hỗ trợ ứng phó khi thiên tai xảy ra } \\
\text { Các Phòng ban chức năng, xã, thị trấn, đoàn thể... sẵn sàng hỗ trợ theo } \\
\text { phân công của BCH PCTT và TKCN và BCH QS }\end{array}$ \\
\hline & Can thiệp & \\
\hline 1 & $\begin{array}{l}\text { Cảnh báo, cứu hộ và } \\
\text { hướng dẫn cách can } \\
\text { thiệp }\end{array}$ & $\begin{array}{l}\text { Ban chỉ huy PCTT và TKCN huyện tổ chức sơ tán dân, đảm bảo an toàn } \\
\text { dân cư theo } 2 \text { hình thức sơ tán tại chỗ và sơ tán di dân ra khỏi vùng bị ảnh } \\
\text { hưởng khi có thiên tai, xác định các đối tượng dễ bị tổn thương để xây } \\
\text { dựng biện pháp ứng phó kịp thời, đảm bảo an toàn an ninh trật tự không } \\
\text { để xảy ra vụ việc lợi dụng mưa bão trộm cắp tài sản của người dân. Di dời } \\
\text { người dân đến trường học, các ủy ban và các công trình kiên cố đảm bảo } \\
\text { đầy đủ cho người dân về đồ ann, nước uống và các nhu cầu yếm phẩm } \\
\text { khác. }\end{array}$ \\
\hline 2 & Giảm thiểu hư hại & $\begin{array}{l}\text { Xác định các đối tượng dễ bị tổn thương để xây dựng biện pháp ứng phó } \\
\text { kịp thời, theo dõi tuyên truyền người dân chằng chống nhà cửa, chuồng } \\
\text { trại, hạn chế đến mức thấp nhất thiệt hại }\end{array}$ \\
\hline \multirow[t]{2}{*}{3} & Các biện pháp khẩn cấp & $\begin{array}{l}\text { Xác định sẵn những nơi trú ẩn an toàn (VD Trường học, cơ quan...) để } \\
\text { có thể di dời người dân thuộc vùng nguy hiểm đến }\end{array}$ \\
\hline & Phục hồi & \\
\hline 1 & Tài chính & $\begin{array}{l}\text { Quỹ phòng chống thiên tai dựa theo Nghị định số 94/2014/NĐ - CP của } \\
\text { Chính phủ quy định về thành lập và quản lý Quỹ phòng, chống thiên tai, } \\
\text { Quyết định số } 196 / \text { Q }- \text { UBND ngày } 17 / 10 / 2018 \text { của Chủ tịch UBND } \\
\text { tỉnh Sóc Trăng Ban hành quy chế tồ chức và hoạt động của quỹ phòng, } \\
\text { chống thiên tai, Quyết định số } 1276 / \text { QĐ- UBND ngày } 29 / 3 / 2019 \text { phê } \\
\text { duyệt Kế hoạch thu Quỹ Phòng, chống thiên tai trên địa bàn huyện Mỹ } \\
\text { Xuyên năm 2019. }\end{array}$ \\
\hline 2 & Bài học kinh nghiệm & Tổ chức hội nghị sơ kết, tổng kết công tác PCTT và TKCN \\
\hline
\end{tabular}

Nhìn chung, công tác chuẩn bị, ứng phó tại vùng nghiên cứu đang được thực hiện tốt trong điều kiện thiên tai diễn biến ngày càng phức tạp và ảnh hưởng đến đời sống người dân. Kết quả khảo sát cho thấy trên $80 \%$ hộ dân đánh giá công tác được thực hiện tốt (Hình 11). Tuy nhiên một số hạn chế còn tồn tại như: Việc ứng phó và phục hồi sau thiên tai chủ yếu dựa vào nguồn lực huy động tại chỗ từ địa phương (theo phương châm "4 tại chỗ"). Việc huy động này giúp phát huy tối đa nguồn lực địa phương, giúp công tác ứng phó nhanh chóng, tiết kiệm thời gian đồng thời hạn chế chi phí điều động từ nơi khác. Tuy nhiên, điều này cũng gây một số hạn chế như: (1) Số lượng trang thiết bị huy động không đủ đáp ứng nhu cầu, (2) Lực lượng thanh tiên đăng ký tham gia công tác ứng phó tại địa phương có thể không đảm bảo do nhiều thanh niên đi làm ăn xa (chẳng hạn phong trào di cư lên các thành phố lớn làm việc như hiện nay). Do vậy, công tác này có thể gặp khó khăn và không đảm bảo nguồn nhân lực khi cần. Bên cạnh đó, kế hoạch ứng phó trong các trường hợp khẩn cấp chủ yếu dựa theo phương châm "4 tại chỗ" bao gồm tận dụng các trụ sở cơ quan, trường học... làm địa điểm 
trú ẩn và sẵn sàng di dân đến vùng an toàn khi gặp tình huống nguy cấp. Do vậy, trong những tình huống khẩn cấp công tác ứng phó có thể gặp khó khăn, lúng túng do chưa có phương án cụ thể. Ngoài ra, công tác chuẩn bị cho từng cá nhân mặc dù đã được thực hiện bằng việc tuyên truyền qua đài phát thanh, loa, băng rol, họp ấp... nhưng vẫn gặp một số vấn đề như: (1) Số lượng loa ít, (2) Chất lượng loa kém nên người dân nghe không rõ, (3) Một bộ phận người dân chủ quan không để ý đến thông báo của địa phương... Bên cạnh đó, việc phục hồi sau thiên tai còn gặp khó khăn do hạn chế về kinh phí. Cụ thể, mức hỗ trợ hiện tại là 1 triệu đồng/căn nhà bị hư hại, do đó, chỉ mang ý nghĩa động viên tinh thần cho người dân là chính chứ chưa đủ để khắc phục thiệt hại.
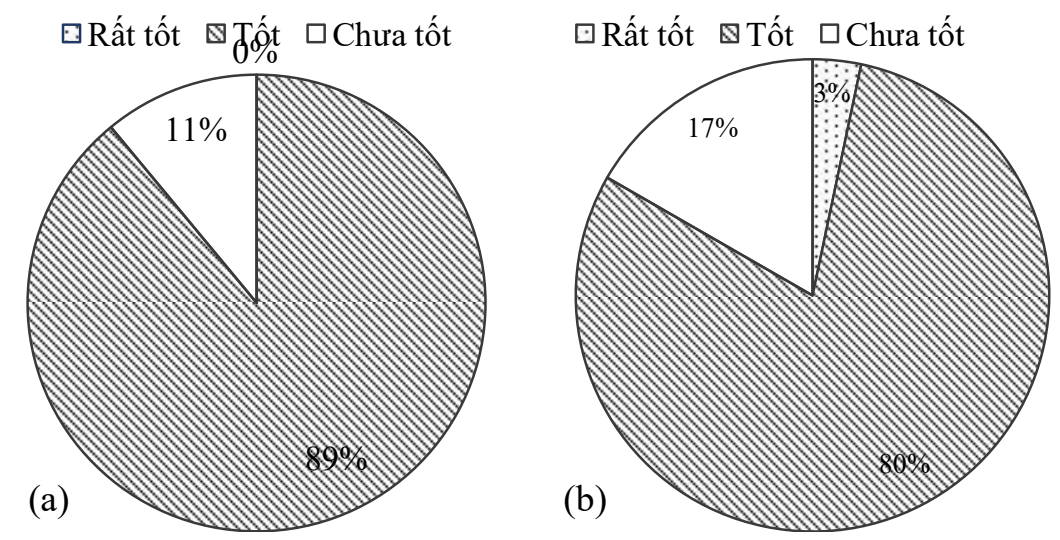

Hình 11. Đánh giá của người dân về công tác ứng phó $(\mathrm{A})$ và phục hồi sau thiên tai $(\mathrm{B})$ của chính quyền địa phương.

\section{Kết luận}

Kết quả nghiên cứu cho thấy trên địa bàn huyện có 3 loại thiên tai thường xuyên xuất hiện gồm: (1) Xâm nhập mặn, (2) giông lốc, (3) bão và ATNĐ. Nhìn chung, các loại hình thiên tai này có xu hướng tăng. Cụ thể XNM tăng về nồng độ mặn và thời gian XNM (với độ mặn $>2 \mathrm{~g} / \mathrm{L}$ ); giông lốc, bão và ATNĐ tăng về tần xuất xuất hiện. Trong các mô hình sản xuất chính của huyện thì mô hình chuyên lúa được đánh giá chịu thiệt hại nặng nề nhất do tác động của xâm nhập mặn so với mô hình lúa-tôm và chuyên tôm. Trong khi đó, mô hình chuyên tôm và lúa-tôm có khả năng rủi ro cao hơn với bão và $\mathrm{ATNĐ.}$

Công tác tổ chức ứng phó và phục hồi sau thiên tai tại huyện Mỹ Xuyên chặt chẽ, có sự tham gia của nhiều bên liên quan với các chức năng, nhiệm vụ cụ thể có thể hỗ trợ, bổ sung cho nhau; trong đó, $\mathrm{BCH} P C T T$ và $\mathrm{TKCN}$ và $\mathrm{BCHQS}$ giữ vai trò chính. Tuy nhiên, vai trò của người dân (hộ gia đình) chưa được đề cao trong công tác này. Bên cạnh đó, một số điểm còn hạn chế như: (1) Việc huy động nguồn lực tại chỗ của địa phương có thể bị động, không đáp ứng đủ số lượng yêu cầu do thanh niên di cư lên các thành phố lớn làm việc; (2) Chưa có nhiều phương án ứng phó với các tình huống khác nhau nên có khả năng lúng túng xử lý tình huống phát sinh; (3) Một bộ phận người dân chủ quan không để ý đến thông báo của địa phương; và (4) Hạn chế về trang thiết bị (loa, đài tuyên truyền) và kinh phí hỗ trợ người dân phục hồi sau thiên tai.

Nghiên cứu bước đầu khảo sát tổng quan về các loại hình thiên tai chính, mức độ thiệt hại đối với các mô hình sản xuất chính và công tác ứng phó, phục hồi sau thiên tai tại địa phương. Tuy nhiên, các số liệu về điều kiện tự nhiên, các loại hình thiên tai chưa được phân tích trong khoảng thời gian đủ dài. Do đó, đề xuất nghiên cứu tiếp theo thu thập thêm các số liệu điều kiên tự nhiên trong giai đoạn dài hơn nhằm đánh giá chính xác hơn xu hướng biến động. Bên cạnh đó, điều tra kinh tế xã hội chi tiết hơn về chi phí đầu tư, yêu cầu kỹ thuật của các loại hình sản xuất chính tại địa phương, chi phí chuyển đổi giữa các mô hình (nếu xảy 
ra) nhằm có đánh giá chi tiết hỗ trợ chính quyền và người dân địa phương trong việc chuyển đổi mô hình phù hợp, hạn chế tác động của thiên tai.

Đóng góp của tác giả: Xây dựng ý tưởng nghiên cứu: N.H.T.; Lựa chọn phương pháp nghiên cứu: N.H.T., V.T.P.L., V.Q.T.; Thu thập số liệu: V.T.P.L.; Xử lý số liệu: V.T.P.L., V.Q.T.; Viết bản thảo bài báo: V.T.P.L., V.Q.T.; Chỉnh sửa bài báo: V.T.P.L., V.Q.T., N.H.T.

Lời cảm ơn: Nghiên cứu này được tài trợ bởi Dự án Hợp tác Kỹ thuật “Tăng cường năng lực Trường Đại học Cần Thơ thành trường xuất sắc về đào tạo, nghiên cứu khoa học và chuyển giao công nghệ" của Cơ quan Hợp tác Quốc tế Nhật Bản (JICA). Tác giả xin cám ơn ban biên tập và hai phản biện đã góp ý để bài báo được hoàn thiện hơn.

Lời cam đoan: Tập thể tác giả cam đoan bài báo này là công trình nghiên cứu của tập thể tác giả, chưa được công bố ở đâu, không được sao chép từ những nghiên cứu trước đây; không có sự tranh chấp lợi ích trong nhóm tác giả.

\section{Tài liệu tham khảo}

1. FAO. Impact of natural disasters and crises on food security and agriculture. 2017. http://www.fao.org/3/I8656EN/i8656en.pdf. Accessed on August 10, 2019

2. Paprotny, D.; Terefenko, P. New estimates of potential impacts of sea level rise and coastal floods in Poland. Nat. Hazards 2017, 85, 1249-1277.

3. Xian, S.; Yin, J.; Lin, N.; Oppenheimer, M. Influence of risk factors and past events on flood resilience in coastal megacities: Comparative analysis of NYC and Shanghai. Sci. Total Environ. 2018, 610, 1251-1261.

4. Genua-Olmedo, A.; Temmerman, S.; Ibáñez, C.; Alcaraz, C. Evaluating Adaptation Options to Sea Level Rise and Benefits to Agriculture: The Ebro Delta Showcase. $\begin{array}{lllll}\text { Sci. Total Environ. } & \text { 2022, } & 806, & 150624 .\end{array}$ https://doi.org/10.1016/J.SCITOTENV.2021.150624.

5. Hương, H.T.L.; Hiển, N.X.; Thủy, N.T.; Hằng, V.T.; Công, N.T. Đánh giá rủi ro thiên tai do lũ lụt khu vực Trung Trung Bộ. Tạp chi Khí tuợng Thủy văn 2020, 715, $13-26$.

6. Hà, H.T.N.; Đại, T.H.; Học, T.Q.; Dũng, B.Q.; Sơn, N.H. Đánh giá rủi ro thiên tai liên quan đến biến đổi khí hậu dựa vào cộng đồng cho các xã ven biển tỉnh Quảng Bình. Tạp chí Khoa học Biến đổi Khi hậu 2020, 16, 83-92.

7. Văn, C.T.; Sơn, N.T.; Tuấn, N.T.; Tiến, N.X. Đánh giá ảnh hưởng của sử dụng đất đến kết quả tính toán chỉ số dễ bị tổn thương do lũ - Áp dụng tính cho huyện Điện Bàn tỉnh Quảng Nam thuộc hạ du lưu vực sông Thu Bồn. Tạp chi Khí tượng Thủy văn 2014, 643, 40-44.

8. Cát, V.M. Đánh giá rủi ro thiên tai do lũ lụt sông Dinh. Tạp chí Khí tượng Thủy văn 2020, 717, 1-10.

9. Trần, T.T.T. Nghiên cứu đánh giá mức độ rủi ro lũ lụt tỉnh An Giang trong trường hợp lũ cao và đề xuất các biện pháp quản lý. Luận văn thạc sỹ, Đại học Quốc gia Hà Nội, Việt Nam, 2019.

10. Tín, T.M.; Long, V.V.; Điệp, T.H.; Minh, V.Q. Úng dụng phân tích đa tiêu chí trong đánh giá ảnh hưởng của biến đổi khí hậu đối với sản xuất nông nghiệp ở các tỉnh ven biển đồng bằng sông Cửu Long, Việt Nam. Tạp chi Khoa học Đại học Cần Tho 2018, $54,202-210$.

11. Tỷ, T.V.; Hoài, Đ.T.T.; Minh, H.V.T. Xây dựng bản đồ hạn hán đồng bằng sông Cửu Long bối cảnh biến đồi khí hậu. Tạp chí Khoa học Đại học Cần Tho, Chuyên đề Môi truờng và biến đổi khi hậu 2015, 226-233.

12. Luật Phòng chống thiên tai số 33/2013/QH13, 2013. 
13. Khiêm, N.V.; Hương, H.T.L.; Khiêm, M.V.; Hương, Đ.T.; Chung, N.N. Hiệu quả, đóng góp của ngành công an trong công tác ứng phó với biến đổi khí hậu, phòng chống thiên tai và tìm kiếm cứu nạn. Tạp chi Khí tượng Thủy văn 2021, 730, 53-67.

14. Tùng, S.T.; Lan, N.H.M.; Nguyên, N.H.; Hương, Đ.N.T.; Vân, P.Đ.B.; Trang, N.T.T.; Hà, B.T.M. Nhận diện "niềm tin" tại cộng đồng dân cư ven biển khu vực Nam Trung bộ trong ứng phó với thiên tai. Tạp chí Khoa học Đại học Thủ Dầu Một 2020, 5(48), 40-49.

15. Thong, T.A.; Romina, R. Integrating farmers' Adaptive Knowwledge into Flood Management and Adaptation policies in the Vietnamese Mekong Delta: A social Learning Perspective. Global Environ. Change 2019, 55, 84-96.

16. Kien, N.T.; Mewett, H.F.; Dharmalingam, A. Social support from bonding and bridging relationships in disaster recovery: Findings from a slow- onset disaster. International Journal of Disaster Risk Reduction 2020, 46, 101501.

17. FOCP. Integrated Risk Management: Its importance in protecting people and their livelihoods. Federal Office for Civil Protection FOCP. 2014, pp. 20.

18. IPCC. Climate change 2007: The physical science basis. Contribution of workinggroup I to the fourth assessment report of the intergovernmental panel on climate change. Solomon, S.; Qin, D.; Manning, M.; Chen, Z.; Marquis, M.; Averyt, K.B.; Tignor, M.; Miller, H.L. (eds). Cambridge University Press, Cambridge, United Kingdom and New York, NY, USA, 2007, pp. 996.

19. Luo, T.; Maddocks, A.; Iceland, C.; Ward, P.; Winsemius, H. World's 15 Countries with the Most People Exposed to River Floods, 2015. Avaliable online: https://www.wri.org/blog/2015/03/world's15 countries most people exposed river floods

20. Trung tâm Kỹ thuật Môi trường Sóc Trăng. Nghiên cứu số liệu, hiện tượng nhiều năm về khí tượng thủy hải văn, diễn biến xâm nhập mặn và đánh giá tình hình $\mathrm{BĐKH}$ và nước biển dâng tại tỉnh Sóc Trăng, 2010.

21. Vũ, P.T.; Vũ, P.H.; Huy, V.T. Sự thay đổi mô hình cảnh tác theo khả năng thích ứng của người dân tại các huyện ven biển Sóc Trăng và Bạc Liêu. Tạp chí Khoa học Truờng Đại học Cần Tho 2013, 26, 46-54.

22. Ban Chỉ huy Phòng chống Thiên tai và Tìm kiếm Cứu nạn huyện Mỹ Xuyên. Kế hoạch phòng, chống thiên tai và tìm kiếm cứu nạn năm 2016-2020.

23. Nhẫn, P.P.; Thùy, P.M. Ảnh hưởng mặn và vai trò của Natri silicate trên lúa ở giai đoạn mạ. Khoa học \& Bản tin, Phân B: Khoa học Nông nghiệp, Thủy sản và Công nghẹ sinh hoc 2011, 19, 187-196.

24. Doorenbos, J.; Kassam, A.H.; Bentvelsen, C.; Uittenbogaard, G. Yield Response to Water. Irrig. Agric. Dev. 1980, 257-280. https://doi.org/10.1016/b978-0-08-0256757.50021-2.

25. Salemi, H.; Amin, M.; Soom, M.; Lee, T.S. Effects of Deficit Irrigation on Water Productivity and Maize Yields in Arid Regions of Iran. Pertannika J. Trop. Agric. Sci. 2011, 34(2), 207-216. 


\title{
A study on climate-related disasters risk assessment in My Xuyen District, Soc Trang Province
}

\author{
Vo Thi Phuong Linh ${ }^{1}$, Nguyen Hieu Trung ${ }^{2}$, Vo Quoc Thanh ${ }^{1 *}$ \\ 1 College of Environment and Natural Resources, Can Tho University; \\ vtplinh@ctu.edu.vn, quocthanh@ctu.edu.vn \\ 2 Research Institute for Climate Change, Can Tho University; nhtrung@ctu.edu.vn
}

\begin{abstract}
The study was conducted to assess the process of coping with and recovering from climate-related disasters (before, during and after the events) in My Xuyen district, Soc Trang province, Vietnam. The data on types of climate-related disasters and damages in the period of 2014 to 2019 was collected from Irrigation Management Station, Department of Agriculture and Rural Development of My Xuyen district. In addition, interviews with farmers and local officials on disaster preparedness, response and recovery have been applied by households and localities. We used a non-parametric test (KruskalWallis) to compare whether or not the difference in the level of damages caused by climaterelated disasters is different for different types of land uses. The process of response and recovery after climate-related disasters was discussed in participation workshops with stakeholders from the Steering Committee for Disaster Prevention and Search and Rescue, People's Committees of communes, and the related departments. The results show that 3 popular types of climate-related disasters were found in My Xuyen, consisting of (1) saline intrusion, (2) cyclones, (3) storms and tropical depressions. In general, these types of climate-related disasters tend to increase from 2014 to 2019. Measures have been applied to response to climate-related disasters are adjustment of cropping calendar and operating the system of irrigation works to cope with the salinity intrusion, measure to recover damages. The government applies an approach of 4-on-the-spot motto in disaster prevention and mitigation which are on-the-spot command, on-the-spot forces, on-site supplies and onsite logistics to take advantages of the local resources, organize to save people injured by storms and tropical depression, organize searching for the missing people. In general, the local recovery process is well organized with the participation of several stakeholders and the support of the local people. However, in this process, this study still finds some difficulties such as limits of equipment, budget, and awareness of local people to proactively coping with climate-related disasters.
\end{abstract}

Keywords: Disaster prevention; Saline intrusion; Disaster mitigation; Mekong Delta; Rice cultivation. 